\title{
MARINE-EXPRESS: taking advantage of high throughput cloning and expression strategies for the post-genomic analysis of marine organisms
}

\author{
Agnès Groisillier ${ }^{\dagger 1,2}$, Cécile Hervét1,2, Alexandra Jeudy 1,2, Etienne Rebuffett,2, Pierre F Pluchon³, Yann Chevolot ${ }^{4}$, \\ Didier Flament 3 , Claire Geslin³, Isabel M Morgado5, Déborah Power ${ }^{5}$, Margherita Branno ${ }^{6}$, Hervé Moreau 7 , \\ Gurvan Michel1,2, Catherine Boyen 1,2 and Mirjam Czjzek*1,2
}

\begin{abstract}
Background: The production of stable and soluble proteins is one of the most important steps prior to structural and functional studies of biological importance. We investigated the parallel production in a medium throughput strategy of genes coding for proteins from various marine organisms, using protocols that involved recombinatorial cloning, protein expression screening and batch purification. This strategy was applied in order to respond to the need for postgenomic validation of the recent success of a large number of marine genomic projects. Indeed, the upcoming challenge is to go beyond the bioinformatic data, since the bias introduced through the genomes of the so called model organisms leads to numerous proteins of unknown function in the still unexplored world of the oceanic organisms.

Results: We present here the results of expression tests for 192 targets using a 96-well plate format. Genes were PCR amplified and cloned in parallel into expression vectors pFO4 and pGEX-4T-1, in order to express proteins N-terminally fused to a six-histidine-tag and to a GST-tag, respectively. Small-scale expression and purification permitted isolation of 84 soluble proteins and 34 insoluble proteins, which could also be used in refolding assays. Selected examples of proteins expressed and purified to a larger scale are presented.

Conclusions: The objective of this program was to get around the bottlenecks of soluble, active protein expression and crystallization for post-genomic validation of a number of proteins that come from various marine organisms. Multiplying the constructions, vectors and targets treated in parallel is important for the success of a medium throughput strategy and considerably increases the chances to get rapid access to pure and soluble protein samples, needed for the subsequent biochemical characterizations. Our set up of a medium throughput strategy applied to genes from marine organisms had a mean success rate of $44 \%$ soluble protein expression from marine bacteria, archaea as well as eukaryotic organisms. This success rate compares favorably with other protein screening projects, particularly for eukaryotic proteins. Several purified targets have already formed the base for experiments aimed at post-genomic validation.
\end{abstract}

\section{Background}

The marine environment is highly complex and contains the vast majority of known and unknown biodiversity. It is also the last frontier to understand the control of the global climate and hides a wealth of biological resources

* Correspondence: czjzek@sb-roscoff.fr

1 UPMC Univ Paris 6, UMR 7139 Végétaux marins et Biomolécules, LIA DIAMS,

Station Biologique, F 29682, Roscoff, France

+ Contributed equally

Full list of author information is available at the end of the article still to be tapped for food, health and energy. Up until very recently, few genomic data were available for oceanic organisms, but this panorama is rapidly changing with a number of genomic projects now underway, which focus on marine organisms, ranging from microbes $[1,2]$ to multicellular eukaryotes including vertebrates or macroalgae [3], as well as the generation of resources and access to genomes or EST libraries for various eukaryotic systems [4-7]. The wealth of sequence data arising from 
these projects, means that researchers are confronted with a huge number of putative genes, the function of which are, at best, so far only deduced from sequence comparisons (automatic annotation). The pressing question is how to analyze the genomic data with respect to original biological processes in diverse marine organisms (i.e. their development or stress response), their importance in adaptation to the particular habitat and how to identify new enzymes and/or metabolites of biotechnological interest. Thus, the availability of complete genome data has resulted in the development of transcriptomic and proteomic methods that can be used to study regulatory networks and interactions of thousands of genes in parallel, allowing an efficient global analysis of genomic information. However, there are a number of clear drawbacks with these methods in so far that they are strongly dependent on the quality of the genome annotation, which at present assumes conserved functions across often widely distant taxa. Furthermore, these techniques give at most only an indication of the regulation/metabolic pathway the corresponding gene product belongs to, and little or no information on the precise biochemical function of unknown genes.

To understand the precise biological function of a single gene, the biochemical and physiological characterization of its product is essential and this is often greatly aided by the availability of 3-D structural information. Although the 3D structure does not always reveal the natural substrate, it has been shown repeatedly that it helps at least find the class of compounds among which the substrate will be found $[8,9]$. Several bottlenecks exist in the analysis of individual proteins; generally the techniques utilized require systems for the efficient over- expression of the target gene in order to produce sufficient recombinant protein. Furthermore, to constitute an assessment for potential biotechnological applications of the discovered proteins/enzymes, the effective recombinant expression of biologically active proteins is essential. When aiming at the 3D-structure of the protein of interest, a second bottleneck is encountered at the step of crystallization of these proteins. Recent developments in the field of structural genomics have demonstrated that medium/high throughput strategies are most adapted to the production of large numbers of soluble and active gene products and/or protein crystals at a time [10,11], since they allow simultaneous testing of numerous conditions with an optimized effort.

In this study, our objective was to set up and apply a medium throughput strategy for the production, expression and, at least for some candidates, the crystallization of selected proteins from marine organisms. With this approach, we targeted proteins from various marine organisms including archaea, bacteria and eukaryotes but also proteins from different families of interest as for example enzymes involved in the metabolism of carbohydrates, stress related proteins or cellular division proteins (Table 1). On the basis of its ease of genetic manipulation, its rapid growth rate, low cost and robustness Escherichia coli still remains the most popular expression system [12]. Moreover, the results of high-throughput programs (such as those funded under the NIH Protein structure Initiative (PSI) [13] available on the site PSI/targetDB http:// targetdb.pdb.org/ show that in term of full-length proteins, up to $50 \%$ of proteins from the Eubacteria or Archaea and $10 \%$ of proteins from Eukarya can be expressed in E. coli in soluble form [14]. We have there-

Table 1: Availability of genomic data to the Marine Express partners.

\begin{tabular}{lllll}
\hline \multicolumn{1}{c}{ Organism } & Taxonomy & \multicolumn{1}{c}{ Gene families of interest } & State of genomic data & Partner \\
\hline Pyrococcus abyssi & Euryarchaeota & $\begin{array}{l}\text { Proteins from the DNA replication } \\
\text { system }\end{array}$ & Genome published [1] & $\begin{array}{l}\text { IFREMER } \\
\text { Brest, France }\end{array}$ \\
\hline Zobellia galactanivorans & Flavobacteria & Polysacchride metabolism, sulfatases & Genome complete & SBR Roscoff, France \\
\hline Ectocarpus siliculosus & Brown alga & $\begin{array}{l}\text { Stress related genes, carbohydrate } \\
\text { active enzymes }\end{array}$ & $\begin{array}{l}\text { 14000 ESTs, Genome } \\
\text { complete }\end{array}$ & SBR Roscoff, France \\
\hline Ostreococcus tauri & Green microalga & Biological clock & Genome published [4] & Arago Banyuls, France \\
\hline Ciona intestinalis & Urochordate & Hox-genes, Ci-msx, Ci-RX & Genome published [5] & SZ A. Dohrn, Napoli, Italia \\
\hline Sparus aurata & Teleost fish & $\begin{array}{l}\text { Hormones, calcium and musculo- } \\
\text { skeletal development, stress related }\end{array}$ & $\begin{array}{l}\text { 30000 ESTs and 20 full } \\
\text { length cDNAs }\end{array}$ & CCMAR Faro, Protugal \\
\hline Archaeal virus (PAV1) & Not yet classified & Any & Genome published [28] & UBO, LM2E, Brest, France \\
\hline
\end{tabular}


fore chosen this expression system for our purpose and report the results of the parallel expression strategy in $E$. coli 192 targeted genes, in two compatible expression vectors, using a 96-well plate format. A selection of individual targets that were successfully overexpressed in this program, were subsequently further characterized in order to determine their functional partners, cellular localization, 3D structure and/or biochemical activity. As a conclusion, three selected examples of these studies are briefly discussed.

\section{Results}

\section{Selection and bioinformatics analysis of the target genes}

A subset of 200 target genes was selected by the different partners involved in the program to evaluate the potential for heterologous expression of marine organism genes in E. coli. The gene families of interest, defined by the partners and organized according to the organism of origin and from three domains of life, are shown in Table 2. The sequences of the genes and their corresponding predicted proteins were analyzed by bioinformatic tools to assess their suitability for expression in our bacterial medium throughput strategy. The nucleotide-sequences were screened for the absence of the selected restriction sites for the gene cloning strategy. Where possible, the potential signal peptides and transmembrane domains were removed in order to express soluble proteins. These were therefore identified using SignalP and TMHMM servers, respectively $[15,16]$. Another important feature that was analyzed in this step was the protein modularity. It is often assumed that single domains of proteins contain important biological functions and are more likely to be successfully expressed than the large, multi-modular proteins. Moreover, the modularity of a protein is usually an obstacle to its crystallization. Consequently, targeted proteins were, where possible, cloned as full length proteins, but also in the form of their individual modules. The modular architecture of each target was examined using Blast queries against UniProt database, as well as domain searches with the InterPro server [17]. The crucial choices of the $\mathrm{N}$ - and $\mathrm{C}$-terminal boundaries of each module were refined using Hydrophobic Cluster Analysis (HCA) [18]. From 200 starting sequences, eighteen were eliminated after restriction site analysis and eight because of the presence of transmembrane zones throughout the protein sequences.. Finally, 192 sequences encoding proteins ranging from 7 to $140 \mathrm{kDa}$ were analyzed and classified according to different restriction site strategies as follows: BamHI/EcoRI, BamHI/MfeI, BglII/EcoRI and $B g l \mathrm{II} / \mathrm{MfeI}$.

\section{Amplification and cloning of DNA fragments}

To optimize the amplification steps through PCR, specific primers were designed which had the same theoretical $\mathrm{T}_{\mathrm{m}}$ value for all targets.

The starting genetic material was genomic DNA for prokaryotes and full length cDNA for eukaryotic organisms. Therefore, in parallel to the bioinformatic analysis, an important step for eukaryotic proteins was to retrieve full length cDNAs from the genetic material. This step was performed separately by each partner by $5^{\prime} \mathrm{RACE}$ PCR on available cDNA libraries. Selected target genes were amplified by PCR using a general set of gene-specific primers (cf Methods). Even non-amplified targets were included in subsequent steps and permitted recovery of two genes in the cloning step. Overall, 183 out of 192 PCR fragments were obtained (Figure 1). These recovered, non-amplified genes corresponded to cDNA (obtained in weak concentration) or genomic DNA with a size greater than 3500 base pairs.

In the present study, two expression vectors were used to test recombinant protein expression and solubility.

Table 2: Comparison of obtained results covering three domains of living organisms

\begin{tabular}{|c|c|c|c|c|c|c|c|c|c|}
\hline & \multicolumn{2}{|c|}{ Eukarya } & \multicolumn{2}{|c|}{ Bacteria } & \multicolumn{2}{|c|}{ Archaea } & \multicolumn{3}{|c|}{ Total } \\
\hline & pFO4 & pGEX & pFO4 & pGEX & pFO4 & PGEX & pFO4 & pGEX & combinedc \\
\hline number of soluble proteins & 14 & 13 & 13 & 25 & 18 & 26 & 45 & 64 & 84 \\
\hline number of insoluble proteins & 10 & 19 & 4 & 5 & 12 & 24 & 26 & 48 & 34 \\
\hline no expression ${ }^{a}$ & 42 & 37 & 11 & 2 & 31 & 11 & 84 & 50 & 52 \\
\hline no clone ${ }^{b}$ & 8 & 5 & 4 & 0 & 9 & 12 & 37 & 30 & 22 \\
\hline percentage of soluble proteins & $7 \%$ & $7 \%$ & $7 \%$ & $13 \%$ & $9 \%$ & $14 \%$ & $23 \%$ & $33 \%$ & $44 \%$ \\
\hline percentage of soluble + insoluble proteins & $13,00 \%$ & $17 \%$ & $9 \%$ & $16 \%$ & $16 \%$ & $26 \%$ & $37 \%$ & $58 \%$ & $61 \%$ \\
\hline
\end{tabular}




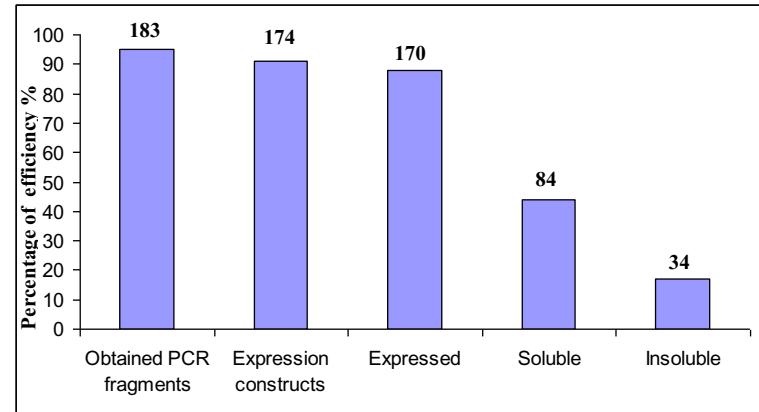

Figure 1 Comparison of protein expression screening success The percentage of success for each step in the protein production pipeline is shown. The number of targets represented at each stage is written above the bars.

One vector (pFO4) contains a $\mathrm{His}_{6}$-tag at the $\mathrm{N}$-terminal for affinity purification; the second (pGEX-4T-1) allows the production of a fusion protein with an N-terminal glutathion-S-transferase (GST). This parallel PCR cloning procedure could easily be performed in 96-well format. The approach relies on the use of a single PCR product for each gene that is compatible for ligation to both the expression vectors, pGEX-4T-1 and pFO4. Since the expression vectors were digested with $\mathrm{BamHI}$ and EcoRI, the upstream and downstream PCR primers introduced BamHI (or its isocaudomer BglII) and EcoRI (or its isocaudomer $M f e \mathrm{I}$ ) restriction sites, respectively, upon PCR amplification. After transformation in E. coli DH5 $\alpha$ strains, the plasmids were validated by PCR screening of colonies using primers specific for the expression vectors and flanking the cloning sites. In this way, we obtained 174 cloned target genes (Figure 1). The efficiency for direct cloning of these target genes from PCR products was $95 \%$ (174 out of 183).

\section{Expression and purification of recombinant proteins in small-scale experiments}

The validated plasmids were used to transform appropriate $E$. coli expression strains (Table 3). Fusion proteins in pFO4 vector are under-control of a T7 promoter and in $E$. coli cells containing a chromosomally located defective prophage DE3 must be used for transformation. For Seventy-seven genes that were cloned from archaea Rosetta or Rosetta (DE3) strains were transformed, which compensate for a number of rare codons in E. coli. For cloned genes that contain several cysteines in their sequences Origami or Origami (DE3) strains (14 genes) were transformed. Indeed, these cells carry mutations for both the thioredoxin reductase $(\operatorname{tr} x B)$ and glutathione reductase (gor) genes, mutations which greatly enhance disulfide bond formation in the cytoplasm. For all other recombinant vectors BL21 or BL21 (DE3) strains were used to be transformed.
For 167 out of 183 cloned constructs that contained inserts of the expected size small-scale experiments for soluble protein expression were screened. A key step in the automation of the small-scale experimental setup is the development of auto-induction media (ZYP5052 medium used in the present study), which contain differentially metabolized carbon sources that promote growth to relatively high cell densities and then auto-induce by the utilization of lactose. These media remove the need to monitor cell densities or to add an inducer such as IPTG in T7-based expression systems [19]. To further optimize soluble protein expression, we used a culture temperature of $20^{\circ} \mathrm{C}$ for 3 days, since it has been established by the Structural Proteomics In Europe consortium [20] and others that lower temperatures tend to be more effective [21]. Moreover, in the present study 24-well plates instead of the usual 96-well plates [14] were used to obtain better aeration of the cells [22]. The final $\mathrm{OD}_{600}$ values that were reached in the small-scale cultivation vessels ranged between 10 and 16 .

The expression and the solubility of the recombinant proteins were tested by SDS-PAGE. Only for few target clones it was possible to visually detect the protein band corresponding to the fusion protein directly on SDSPAGE gels, as illustrated for some examples in Figure 2a. Consequently, to validate the exact number of clones that expressed proteins in the soluble fractions, we used Microspin GST/HIS mini-columns (GE Healthcare Life Science, USA) to perform a mini-purification screen. Indeed, these mini-columns are used to purify a GST fusion protein or a HIS fusion protein by affinity chromatography. After incubation and washing, bound Histagged or GST-tagged proteins were eluted with elution buffer containing imidazole or reducing-glutathion, respectively. The elution results were again analyzed on SDS-PAGE gels (Figure 2b). This evaluation method was much more sensitive and revealed that 118 proteins out of the 174 constructs $(68 \%)$ were expressed, while 84 of these 118 (71\%) were found to be soluble (Table 2 and Additional file 1, Table S1).

\section{Scale-up expression and purification of targets from Pyrococcus abyssi}

A relative high success rate (45\% of solubly expressed targets) was obtained for targets originating from the hyperthermophilic archae Pyrococcus abyssi. A total of 37 out of 77 expressed proteins were expressed soluble and easily purified in the small scale set up. To pursue the biochemical characterization of these proteins, to date the purification of 33 proteins has been performed at a larger scale. The up-scaling was performed using culture volumes of $200 \mathrm{ml}$ and based on the protocols of the medium throughput strategy. Independent of size or protein family, reasonable yields in the range of several $\mathrm{mg}$ of 


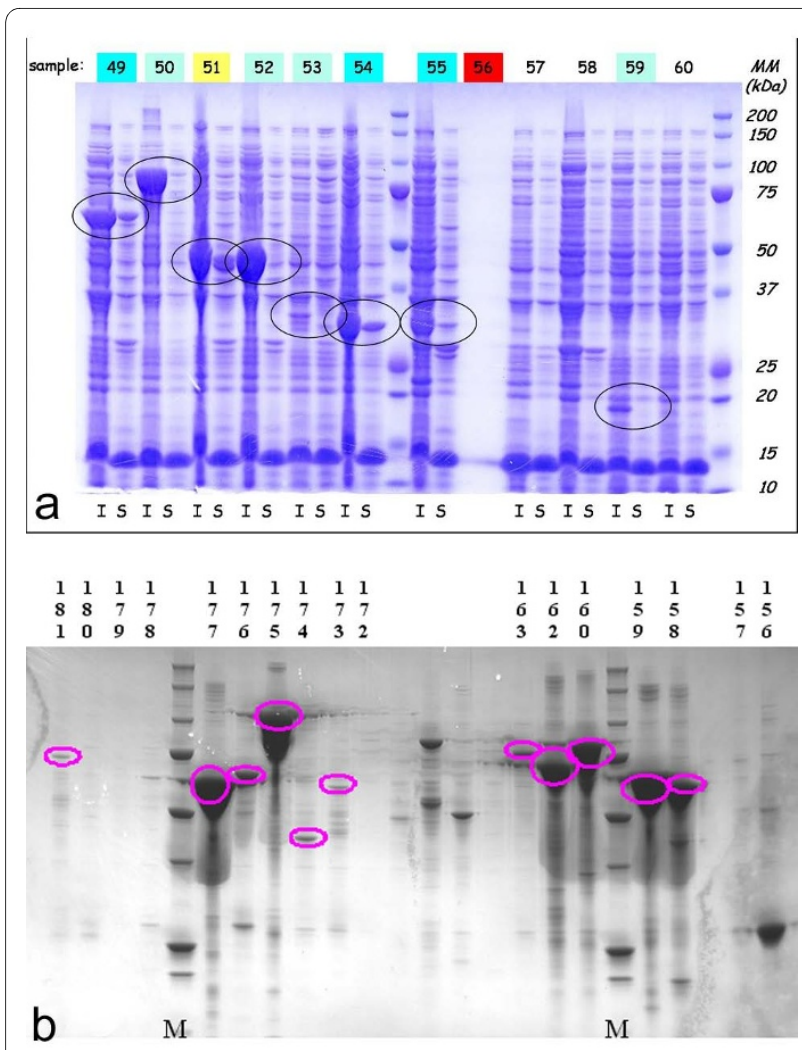

Figure 2 Assessing soluble and insoluble protein expression levels in the medium throughput strategy. a. SDS-PAGE of Insoluble (I) and soluble (S) crude cellular extracts of the E. coli expression cultures. Targets 50 to 60 are shown. Black circles surround bands of correct size for a given target. $\mathbf{b}$. Western-blot using anti-His antibody of selected targets highlighted after purification of soluble cell lysis extracts on mini-affinity (His) columns. Selected targets between 156 and 181 are shown. Pink circles highlight bands of correct size for a given target.

pure protein were obtained for the scaled-up targets, as exemplified by four targets in Figure 3a. One of the aims of the follow-up study based on the genome data of $P$. abyssi is to identify novel partners in the archaeal DNA repair/replication system. The purified and tagged proteins are therefore subsequently used in pull-down/MS experiments as previously described [23]. One example of a successful pull-down experiment is illustrated in Figure $3 \mathrm{~b}$. The up-scaled, produced and purified target 92 (PAb0164, see Additional file 1, Table S1) was immobilized on the column. Interacting proteins were co-purified and subsequently identified using an Ultraflex MALDI-TOF/TOF instrument (Bruker Daltonics).

\section{Up-scale, purification and crystallization of R-Z3597 from Zobellia galactanivorans}

The genome of $Z$. galactanivorans contains approximately $50 \%$ of 'hypothetical proteins', as identified by bioinformatic analysis (Barbeyron et al., in preparation). A selection of these proteins, chosen because of very distant similarity to glycoside hydrolases or because they were collinear and found in close genomic context to other glycoside hydrolases, were targets for the heterologous expression, to produce sufficient pure protein samples for a complete structural and biochemical characterization. In particular, R-Z3597 (target 43, Additional file 1, Table S1) was successfully over expressed in soluble form and in high yield. The scale-up of expression was performed using the protocol established in the medium throughput trial, but for $500 \mathrm{ml}$ culture medium. The final yield after two steps of purification (Nickel affinity and size exclusion) was $15 \mathrm{mg}$ (Figure 4a). A solubility screen, following the strategy of Collins et al. [24] indicated that the best results were obtained with a buffer composed of $50 \mathrm{mM}$ CHES pH 9.5, $500 \mathrm{mM} \mathrm{NaCl}$ and $100 \mathrm{mM}$ imidazole. The protein was concentrated in this buffer to a final concentration of $12 \mathrm{mg} / \mathrm{ml}$. Crystallisation conditions were screened using three different commercial kits (PEGI, PACT and JCSG+). Orthorhombic single crystals grew in the optimized condition, containing 20\% (w/v) PEG 3350 and $200 \mathrm{mM}$ calcium acetate, within one or two weeks at $292 \mathrm{~K}$ (Figure 4b). The further biochemical characterization, especially the screening for activity on various marine oligo- and polysaccharides is currently in progress.

\section{Scale-up, purification and crystallization of Staniocalcin $1 \mathrm{~A}$ from Sparus aurata}

Functional characterization of proteins from Sparus aurata involved in handling and regulation of calcium: several categories of fish cDNA were provided to the flagship project MARINE-EXPRESS and included hormones, hormone responsive transcription factors, chaperones and matrix proteins involved in hormone driven calcium turnover. Target constructs used for further studies included sea bream and Tetraodon nigroviridis Stanniocalcins. In particular the expression of stanniocalcin1 (STCA1) from Tetraodon nigroviridis was scaled-up following the protocol established in the medium throughput trial, but for $500 \mathrm{ml}$ ZYP5052 culture medium. The final yield after two steps of purification (Nickel affinity and size exclusion) was about $12 \mathrm{mg}$ (Figure 5a).

Crystallisation conditions were screened using three variants of commercial kits (PEGI, PACT and JCSG+). First thin, plate-like crystals grew in the condition, containing PEG 4000 25\% $0.1 \mathrm{M}$ di-sodium citrate $\mathrm{pH} 5.6$ and $0.2 \mathrm{M}$ ammonium sulphate, within one or two weeks at $292 \mathrm{~K}$ (Figure 5b). The further biochemical characterization and optimization of crystallization conditions to produce crystals suitable for X-ray analysis is currently under progress. 


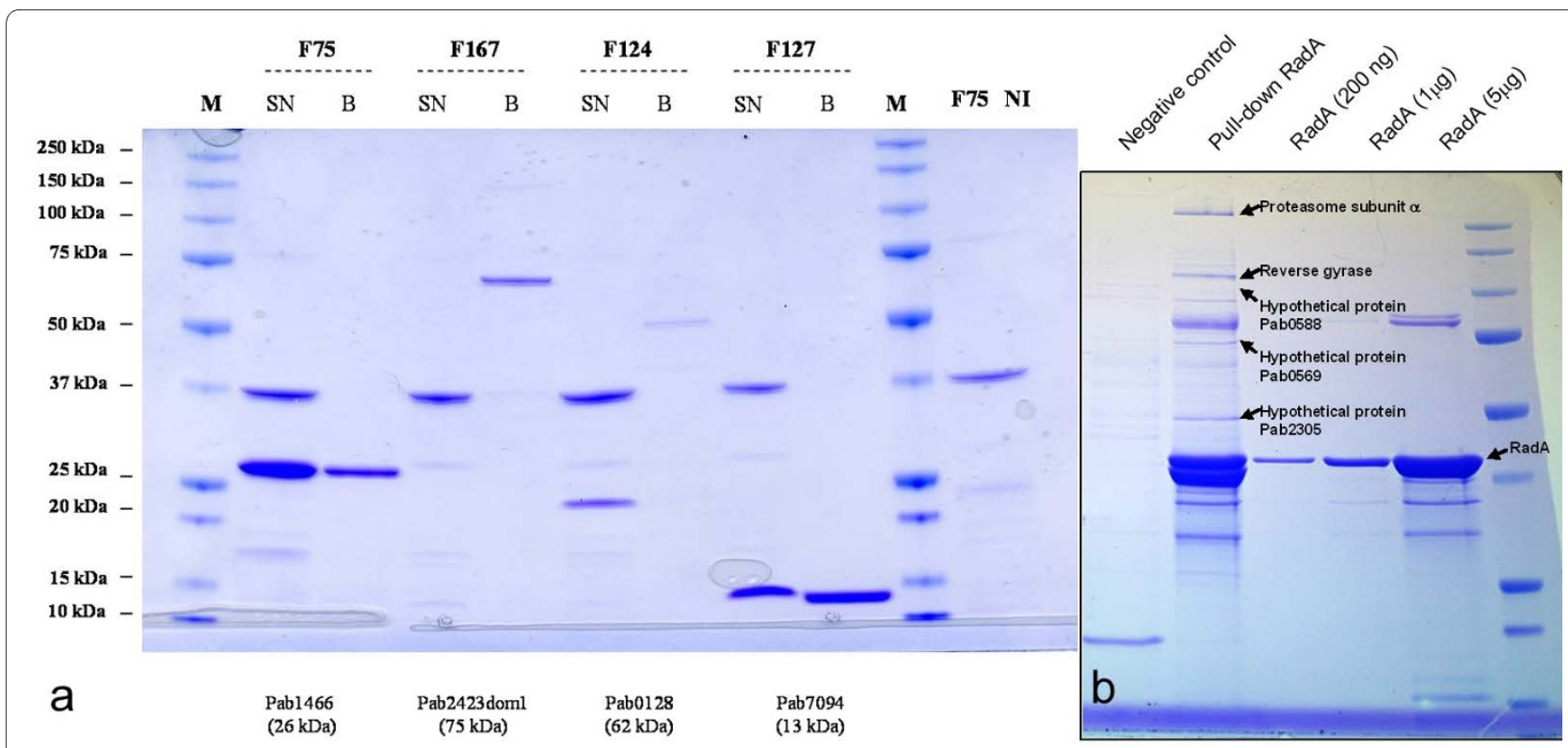

Figure 3 Up-scale and purification of targets from P. abyssi. a. SDS-PAGE gel of up-scaled and purified HIS-tagged targets F75, F124, F127 and F167 before and after final polishing on $\mathrm{CO}^{2+}$ specific beads ( $\mathrm{SN}=$ Supernatant of cell culture; $\mathrm{B}=$ after incubation with Dynabeads TALON; $\mathrm{M}=$ protein markers; F75 = test line; $\mathrm{NI}$ = F75 without induction). b. 12\% SDS-PAGE analysis of a P. abyssi RadA (PAB0164, target 92 round R1) pull-down experiment. Proteins identified using an Ultraflex MALDI-TOF/TOF instrument (Bruker Daltonics) are indicated with arrows.

\section{Discussion}

Based on sequence analysis, a large proportion of genes from genomic data of marine organisms have unknown cellular and/or molecular functions. One major challenge is to assign biological function and to elucidate the mech-

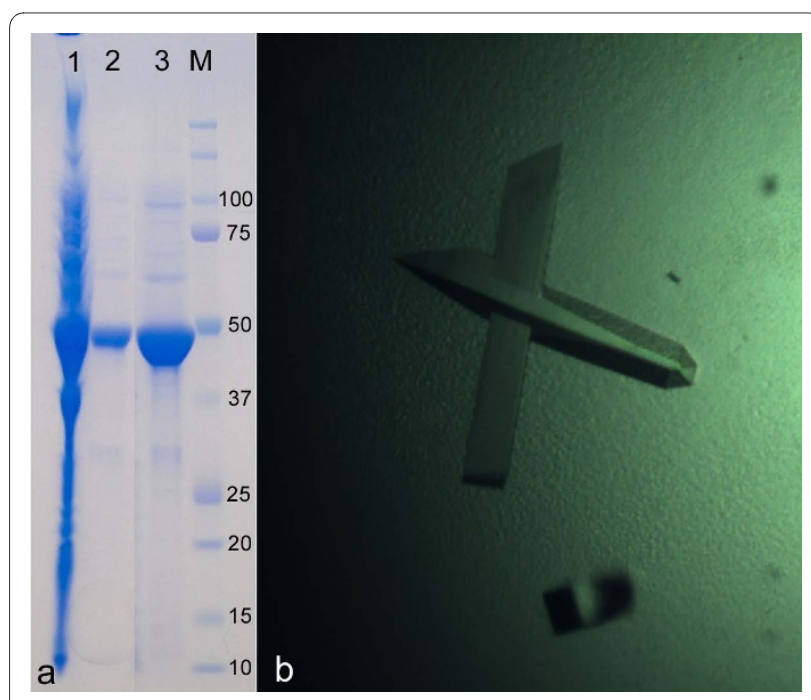

Figure 4 Up-scale purification and crystallization of R-Z3597 from Zobellia galactanivorans. a. SDS-PAGE gel of up-scaled and purified His-tagged target Zg3597. Lane 1, soluble extract; lane 2, purified R-Z3597 by affinity chromatography using a $\mathrm{Ni}^{2+}$-charged resin; lane 3 , R-Z3597 purified by size exclusion gel chromatography; M, standard molecular weight markers. b. Orthorhombic crystals of Zg3597 (0.1 × $\left.0.1 \times 0.5 \mu \mathrm{m}^{3}\right)$ anism of action of such genes. This challenge involves techniques to elucidate the structure and function of the gene products, interactions between proteins and/or global protein changes. For example, the three-dimensional structure of a protein can often provide functional clues, primarily by detecting structural similarity with a protein of known function even when sequence identity is low [9]. Purified protein is generally required in these

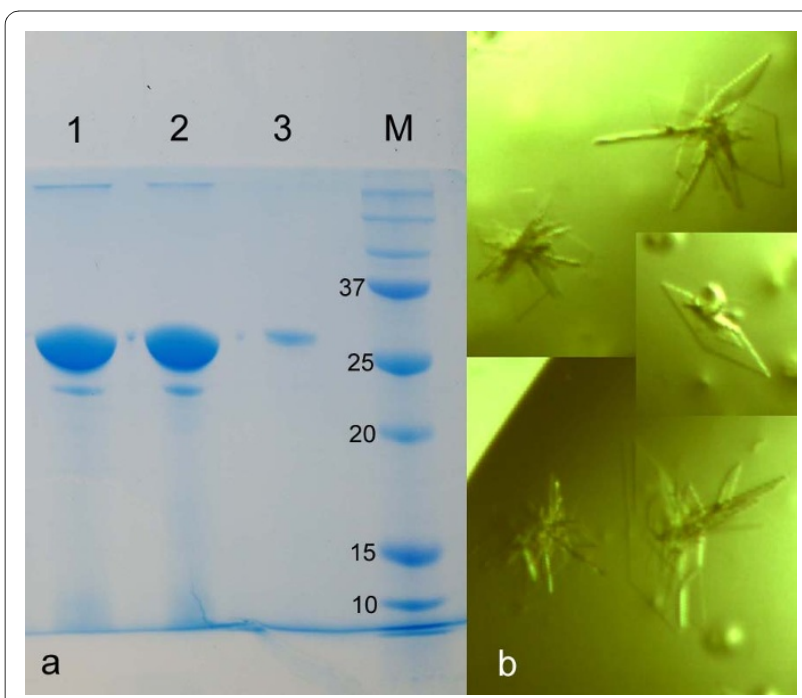

Figure 5 Up-scale purification and crystallization of Stanniocalcin 1 of Sparus aurata. a. SDS-PAGE gel of up-scaled and purified Histagged target STCA1. b. First plate-like crystals of STCA1 (approximate size of $0.05 \times 0.05 \times 0.008 \mu^{3}$ ). 
Table 3: Escherichia coli strains and plasmids used in this study.

\begin{tabular}{|c|c|c|}
\hline & Genotypes and relevant properties & Sources or references \\
\hline \multicolumn{3}{|l|}{ Strains } \\
\hline $\mathrm{DH} 5 \mathrm{a}$ & $\begin{array}{l}\mathrm{F}^{-} \text {endA1 glnV44 thi-1 recA1 relA1 gyrA96 deoR nupG } \varphi 80 \mathrm{~d} / a c Z \Delta \mathrm{M} 15 \Delta(\text { (lacZYA-argF)U169, hsdR17 } \\
\text { (rK- mK+), } \lambda \text { - }\end{array}$ & Promega, USA \\
\hline BL21 & $\mathrm{F}^{-}$ompT gal dcm lon hsdS $\left(r_{B}^{-} m_{B}^{-}\right)$ & Novagen, USA \\
\hline BL21 (DE3) & F-ompT gal dcm lon hsdS $S_{B}\left(r_{B}^{-} m_{B}^{-}\right) \lambda($ DE3 [lacl lacUV5-T7 gene 1 ind1 sam7 nin5]) & Novagen, USA \\
\hline Rosetta & F-ompThsdS ${ }_{B}\left(R_{B}^{-} m_{B}^{-}\right)$gal dcm & Novagen, USA \\
\hline $\begin{array}{l}\text { Rosetta } \\
\text { (DE3) }\end{array}$ & F-ompThsdS ${ }_{B}\left(R_{B}-m_{B}^{-}\right)$gal dcm $\lambda(\mathrm{DE} 3$ [lacl lacUV5-T7 gene 1 ind1 sam7 nin5]) & Novagen, USA \\
\hline Origami & 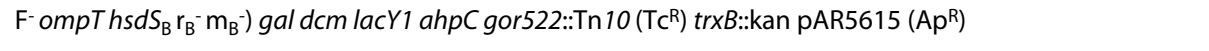 & Novagen, USA \\
\hline $\begin{array}{l}\text { Origami } \\
\text { (DE3) }\end{array}$ & $\begin{array}{l}\left.\mathrm{F}^{-} \text {ompT hsdSB rB- } m B \text {-) gal dcm lacY1 ahpC gor522::Tn10 (TcR) trxB::kan pAR5615 (Ap }{ }^{R}\right) \lambda(\mathrm{DE} 3[\text { lacl lacUV5- } \\
\text { T7 gene } 1 \text { ind } 1 \text { sam7 nin5]) }\end{array}$ & Novagen, USA \\
\hline
\end{tabular}

Plasmids

pGEX-4T1 Amp ${ }^{R}$, tac promoter, GST.Tag

pFO4 Amp ${ }^{R}$, T7lac promoter, His.Tag
GE HealthCare, USA

This Study studies and is at the basis of the development of medium/ high throughput strategies to produce a large number of soluble proteins $[10,11]$. A key feature to the success of medium/high throughput cloning strategies is the optimization of an identical treatment of all targets. Moreover, multiplying constructs, vectors and targets consequently increase the chances to obtain pure, soluble protein samples to pursue biochemical analyses. This has also been demonstrated more recently by other expression systems, such as the ligation-independent cloning (LIC) method of Mycobacterium tuberculosis gene sequences [25].

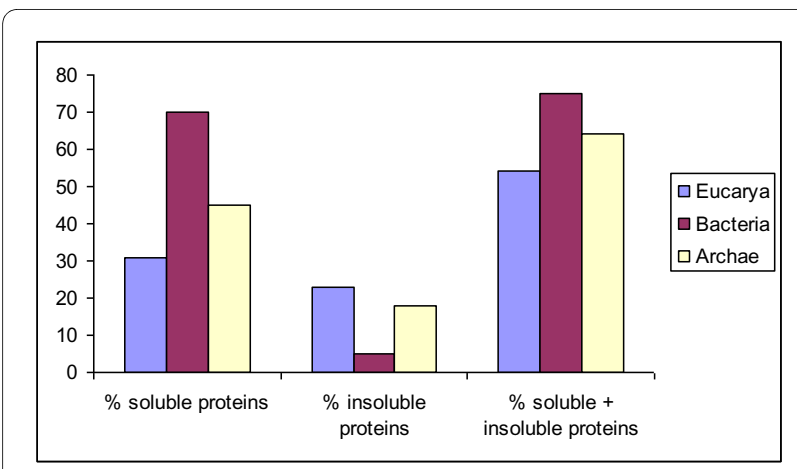

Figure 6 Comparison of soluble and insoluble protein expression percentage in the three-domain system. Global comparison of the successful expression obtained from archaea, bacteria and eukarya. Eukarya are represented by the blue bars, Bacteria are represented by the red bars and Archaea are represented by the yellow bars.
The increased number of genomic projects concerning marine organisms that are available, including prokaryotic organisms [1,2] or eukaryotic organisms [3-7], as well as projects still in progress (Ectocarpus siliculosus, Zobellia galactanivorans), require the application of medium/ high throughput transcriptomic and proteomic methods.

Here, we show that a general scheme for bacterial expression of genes originating from marine organisms could be successfully implemented for the production of soluble proteins. Relatively few studies have been performed to assess medium/high throughput expression of soluble proteins from marine organisms. However, in general efforts have been concentrated on individual organisms. For an example, the Southeast Collaboratory for Structural Genomics has developed high throughput protein production and crystallization of genes originating from Pyrococcus furiosus [26]. More recently, a series of diatom expression vectors based on the Invitrogen Gateway technology for high throughput protein tagging and overexpression in Phaeodactylum tricornutum has been described [27].

In the present study a medium throughput approach was applied for the heterologous protein expression of diverse marine organisms (including prokaryotes, archae and eukaryotes) in the same system (Figure 6). This is in contrast with previous studies that generally focus on one organism of origin. The general concept of the MARINEEXPRESS program can be divided into three main parts: i) the bioinformatics analysis of the target genes selected by different partners, ii) the cloning of targeted genes into 
two different expression vectors and iii) the soluble expression of the targeted proteins. Table 1 shows the MARINE-EXPRESS consortium partners and the main organisms studied. Moreover, we have analyzed target genes from a lemon-shaped Virus-like Particle (PAV1) isolated from the hyperthermophilic euryachaeote Pyrococcus abyssi [28] and some target genes from the brown alga Laminaria digitata and the red alga Chondrus crispus [6,7]. To enhance protein solubility and to facilitate affinity chromatography in the next purification steps, we used a gene fusion approach. Several tags have been developed commercially to facilitate rapid single-step purification $[29,30]$. The most popular are glutathion-Stransferase (GST) [31] and polyhistidine $\left(\mathrm{His}_{6}\right)$ [32] tags. The $\mathrm{His}_{6}$-tag is popular because of its small size. GST fusions help in obtaining soluble products of the whole fusion protein simply by its presence. Each expression scenario requires a specific vector. Re-cloning genes into each of these vectors is extremely labor-intensive. Recombinatorial cloning methods provide an opportunity to minimize the effort required for alternate expression [33]. The present study includes two expression vectors with either a His-tag (pFO4) or GST-tag (pGEX$4 \mathrm{~T}-1)$ at the N-terminal that allow the same restrictionenzyme-based cloning in $B a m H I / E c o R I$. Figure 1 shows an average cloning success superior to $80 \%$. This success rate is clearly higher than those obtained with different organisms [34] or at different centers from the Protein Structure Initiative [13]. The use of auto-induction media for small-scale protein production was successful. This is measured by the high level of target protein expression (>80\%) that has been achieved.

The next stage, analysis of protein expression can be carried out without affinity purification using SDS-PAGE analysis which is a very reliable method, but not very sensitive. Indeed, for direct detection of the His-tagged product in the soluble fraction, a dot-blot procedure with an anti-His antibody is often applied [35-37]. Dot-blot is a fast method to screen expression and solubility of recombinant proteins using a convenient 96-well format. However, the reliability of this method is limited due to lack of specificity of the detection method, and it does not give information about the size and the purity of detected protein. One solution is to couple dot-blot with techniques providing information about the actual size such as capillary electrophoresis, SDS-PAGE or Western blotting. In out study, the use of affinity mini-columns increased the percentage of detected soluble targets by $15 \%$ for Histagged and $60 \%$ for GST-tagged targets. Moreover, this method permitted to the expression level of recombinant proteins to be estimated more precisely and confirmed their correct molecular weight. In fact, the number of obtained soluble proteins is generally under evaluated. Indeed, we have seen that for some targets that were judged negative in small-scale experiments, culturing them in a larger volume of auto-inducible medium, such as $50 \mathrm{ml}$, in some cases allowed soluble expression of these 'negatively' judged targets (data not shown). The triage based on the small-scale results reduces the number of targets that progress to large-scale culture preparation [32], but in rare particular cases misses potential soluble expression.

Previous studies have indicated that approximately $50 \%$ of full-length proteins from the Eubacteria or Archaea and only $10-20 \%$ of proteins from Eucarya can be expressed in E. coli in soluble form [38,39]. This percentage has been significantly increased (nearly $50 \%$ ) for human targets proteins using a multi-construct approach [40]. In the present study, $44 \%$ of soluble proteins were obtained. The best results are obtained for marine bacteria with $67 \%$ of soluble proteins, then archaea with $45 \%$ and as expected, Eucarya give the smallest percentage with $31 \%$. These differences decrease if we take both insoluble and soluble proteins into account (Figure 6). In summary, we used a parallel production approach for bacterial expression in medium throughput to yield 84 soluble proteins from a total of 192 marine targets (44\%).

While expression or crystallization strategies can be generalized to a common factor like their marine bacterial or eukaryotic origin, the setup for the functional screening is intimately bound to the gene family of interest to the different consortium members (Table 1). This latter step, performing the functional/biochemical characterization of the soluble expressed proteins, will therefore be conducted by each partner and will focus on the family of genes of their interest.

In conclusion, the present project provided purified proteins that are key reagents for numerous assays that address fundamental questions about their structure, function and regulation. For the first time, our medium throughput project allowed the expression of various proteins of marine origin in parallel, independent of organism. A rapid and cost-effective small-scale screening method for soluble expression of proteins from marine organisms in E. coli has been established, allowing the different partners to access large quantities of purified protein and to choose among targets of their interest for subsequent functional and/or structural analysis, which is currently underway.

\section{Methods}

\section{Strains, plasmids and culture conditions}

The sources and relevant genotypes of the bacterial strains as well as of the plasmids used are listed in Table 3. Plasmid pGEX-4T-1 (GE Healthcare Life Science, USA) is used to express protein in fusion with a glutathione-Stransferase (GST) at the N-terminal. Plasmid pFO4 (a vector modified from pET15b (Novagen, USA) to be 


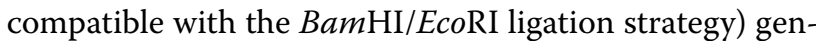
erates a hexa-histidine tail at the $\mathrm{N}$-terminal of recombinant protein. Escherichia coli DH5 $\alpha$, used for standard cloning procedures, and E. coli strains used for gene expression experiments, were grown in Luria-Bertani (LB) liquid or on LB solid medium, as described by Sambrook et al. in 1989 [41]. For expression tests, an autoinducible ZYP5052 medium [19] was used. All media were supplemented, when necessary, with $100 \mu \mathrm{g} \mathrm{ml}^{-1}$ ampicillin (sodium salt).

\section{Bioinformatics analysis of the target sequences}

The potential signal peptides and transmembrane domains have been predicted using SignalP and TMHMM, respectively $[15,16]$. The modularity of each target protein has been examined using Blast queries against UniProt database, as well as domain searches with the InterPro server [17]. The precise delineation of each module has been refined using Hydrophobic Cluster Analysis (HCA) [18]. For this study, 192 modules were chosen with predicted masses between 7 and $140 \mathrm{kDa}$ and rearrayed into two 96 -well plates. All procedures were performed where possible in this 96-well format.

\section{Primers design and cloning method}

Expression vectors (pGEX-4T1 and pFO4) were digested by $B a m \mathrm{HI}$ and $E c o$ RI. For each target sequence, we sought the restriction site recognized by BamHI, EcoRI or their isocaudomers (respectively BglII and $M f e I$ ) using BioEdit Sequence Alignment Editor (Ibis Biosciences Inc., USA). The target genes were classified into four compatible cloning strategies (BamHI/EcoRI, BamHI/ $M f e \mathrm{I}, B g l \mathrm{II} / E c o \mathrm{RI}$ and $B g l \mathrm{II} / M f e \mathrm{I})$ in order to design the correct oligonucleotide primers, and assign targets in 96wells plate). The standard scheme for primer design was defined as: for the forward primers, 5'-[hexa- $G$ tail][BamHI or BglII]-[Hybridization site]-3' and for the reverse primers, 5'-[hexa-C tail]-[EcoRI or MfeI]-[stop anticodon]-[Hybridization site]-3'. Oligonucleotides for PCR were purchased in 96-well plates from Operon Biotechnologies $\mathrm{GmbH}$ (Cologne, Germany). PCR amplification was performed on a GeneAmp PCR System 2700 (Applied Biosystems, USA). The thermocycle utilized was: denaturation at $95^{\circ} \mathrm{C}$ for $5 \mathrm{~min}$ and thirty cycles of denaturing at $95^{\circ} \mathrm{C}$ for $30 \mathrm{~s}$, annealing at $50^{\circ} \mathrm{C}$ for $30 \mathrm{~s}$ and polymerization at $72^{\circ} \mathrm{C}$ for $4 \mathrm{~min}$. Template amplification was performed with Pfu polymerase (PROMEGA, USA) and used with the conditions recommended by the supplier. PCR reactions were analyzed on $1 \%$ agarose gels using standard procedures [41]. The resulting PCR products were purified using the QIAquick ${ }^{\mathrm{mm}} 96$ PCR purification Kit (QIAGEN, USA), digested with appropriate restrictions enzymes and cloned in parallel into the $\mathrm{pFO} 4$ and pGEX-4T1 expression vectors using standard proce- dures [41]. PCR-screening was performed directly on the DH5 $\alpha$ bacterial colonies to verify clones with inserts on expected size, using PCR primers which annealed upstream and downstream of the insertion site of pGEX4T1 and pFO4. Target fragments were amplified using 10 $\mu \mathrm{l}$ of PCR Master Mix (PROMEGA, USA) added to $0.2 \mu \mathrm{l}$ of each primer $(100 \mu \mathrm{M})$ with the same program described above. Plasmid extraction was performed using MiniPrep SV purification Kit (PROMEGA, USA) and recombinant plasmids were used to transform $E$. coli expression strains.

\section{Screening for protein expression using $2 \mathrm{ml}$ cultures}

$E$. coli clones, for which the presence of the expression gene had been verified by colony PCR as described previously, were tested for the expression of the desired protein. Screening was done using $2 \mathrm{ml}$ cultures in 24-deep well plates. Cultivation was performed in two phases. First, transformed colonies were grown at $37^{\circ} \mathrm{C}$ overnight in LB medium containing $100 \mu \mathrm{g} \mathrm{ml}^{-1}$ ampicillin. Then, cultures were diluted 1:100 with auto-inductible ZYP5052 medium [19] containing $100 \mu \mathrm{g} \mathrm{ml}-1$ ampicillin and subjected to further incubation at $20^{\circ} \mathrm{C}$ until the desired density.

\section{Lysis of cells and detection of proteins}

For solubility assay, cell pellets from small-scale expression cultures were resuspended in $500 \mu \mathrm{l}$ of lysis buffer (Tris- $\mathrm{HCl} 50 \mathrm{mM}, \mathrm{pH}$ 7.5; $\mathrm{NaCl} 250 \mathrm{mM}$; EDTA $1 \mathrm{mM}$; lysosyme $1 \mathrm{mg} \mathrm{ml}^{-1}$; DNAse $0.1 \mathrm{mg} \mathrm{ml}^{-1}$ ) and incubated at $18^{\circ} \mathrm{C}$ for 1 hour and the soluble and insoluble fractions separated by centrifugation $\left(12000 \mathrm{~g}, 20 \mathrm{~min}, 4^{\circ} \mathrm{C}\right)$. Insoluble pellets were resuspended in $200 \mu \mathrm{l}$ of lysis buffer supplemented with urea 6 M. Samples from soluble and insoluble fractions were separated by $12 \%$ sodium dodecyl-sulfate polyacrylamide gel electrophoresis (SDSPAGE) using $12 \%$ Criterion precast Bis-Tris gels with 26 wells. Targets were scored as positive for expression and solubility if a detectable fusion protein of the correct molecular weight was observed after Coomassie-staining. In parallel, soluble fractions were purified using His or GST Microspin columns (GE Healthcare Life Science, USA) according to the protocol recommended by the supplier. The results were also analyzed by $12 \%$ SDSPAGE.

\section{Additional material}

Additional file 1 Table S1. Summary of all 192 targets, listing the partners providing the targets, the organism of gene origin, the accession numbe (where known), the primers used for amplification and eventually the follow-up experiments that have been performed. 


\section{Authors' contributions}

GM, CB and MC have set up and designed the study; $A G$ and $C H$ have set up and performed all experiments; $\mathrm{GM}, \mathrm{AG}, \mathrm{CH}$ and $\mathrm{AJ}$ have performed bioinformatic analysis; AJ has performed cloning and expression experiments in round 2; ER, PP and IM have performed up-scale expression, purification and crystallization experiments of selected targets; DF, CG, DP, MB, HM, CB and GM have provided genomic material, as well as access to genomic data and designed follow up experiments. $\mathrm{AG}, \mathrm{CH}$ and $\mathrm{MC}$ have analyzed the data and written the manuscript; all authors discussed the results and commented the manuscript and all authors read and approved the final manuscript.

\section{Acknowledgements}

This work has been funded by the network of excellence (GOCE-CT-2004505403) 'Marine Genomics Europe' through a Flagship program entitled 'Marine-express' (2006-2008). DF is supported by grant 4852-REPAR/CREATE from the Brittany Regional Council. This work was also supported by the ANR program ARCREP (contract number: ANR-07-BLAN-0371-01) to DF and MC.

\section{Author Details}

'UPMC Univ Paris 6, UMR 7139 Végétaux marins et Biomolécules, LIA DIAMS, Station Biologique, F 29682, Roscoff, France, 2CNRS, UMR 7139 Végétaux marins et Biomolécules, LIA DIAMS, Station Biologique, F 29682, Roscoff, France 3/fremer-CNRS-UBO, UMR6197, Microbiology of Extreme Environments, Technopole Brest-Iroise, BP70, 29280 Plouzané, France, 4Institut des nanotechnologies de Lyon (INL), UMR5270, Ecole Centrale de Lyon Bât. F 7, 36 Av Guy de Collongue, 69134 Ecully Cedex, France, ${ }^{5}$ Centro de Ciências do Mar, Universidade do Algarve, Comparative and molecular Endocrinology, 8005-139 Faro, Portugal, ${ }^{6}$ Cellular and Developmental Biology, Stazione Zoologica A. Dohrn, Villa Comunale, 80121 Napoli, Italia and 7Observatoire de Banyuls sur mer, Models in Cellular and Evolutive Biology, UMR7628, CNRS-UPMC. Banyuls sur mer, France

Received: 9 March 2010 Accepted: 14 June 2010

Published: 14 June 2010

\section{References}

1. Cohen G, Barbe V, Flament D, Galperin M, Heilig R, Lecompte O, Poch O, Prieur D, Quérellou J, Ripp R, Thierry JC, Van der Oost J, Weissenbach J, Zivanovic $Y$, Forterre P: An integrated analysis of the genome of the hyperthermophilic archaeon Pyrococcus abyssi. Mol Microbiol 2003, 47:1495-1512

2. Glöckner FO, Kube M, Bauer M, Teeling H, Lombardot T, Ludwig W, Gade D, Beck A, Borzym K, Heitmann K, Rabus R, Schlesner H, Amann R, Reinhardt R: Complete genome sequence of the marine planctomycete Pirellula sp. strain 1. Proc Natl Acad Sci USA 2003, 100:8298-8303.

3. Peters AF, Marie D, Scornet D, Kloareg B, Cock JM: Proposal of Ectocarpus siliculosus (Ectocarpales, Phaeophyceae) as a model organism for brown algal genetics and genomics. J Phycol 2004, 40:1079-1088.

4. Derelle E, Ferraz C, Rombauts S, Rouze P, Worden AZ, Robbens S, Partensky F, Degroeve S, Echeynie S, Cooke R, Saeys Y, Wuyts J, Jabbari K, Bowler C, Panaud O, Piegu B, Ball SG, Ral JP, Bouget FY, Piganeau G, De Baets B, Picard A, Delseny M, Demaille J, Van de Peer Y, Moreau H: Genome analysis of the smallest free-living eukaryote Ostreococcus tauri unveils many unique features. Proc Natl Acad Sci USA 2006 , 103:11647-11652

5. Dehal P, Satou Y, Campbell RK, Chapman J, Degnan B, De Tomaso A Davidson B, Di Gregorio A, Gelpke M, Goodstein DM, Harafuji N, Hastings KE, Ho I, Hotta K, Huang W, Kawashima T, Lemaire P, Martinez D, Meinertzhagen IA, Necula S, Nonaka M, Putnam N, Rash S, Saiga H, Satake M, Terry A, Yamada L, Wang HG, Awazu S, Azumi K, Branno M, Chin-Bow S, DeSantis R, Doyle S, Francino P, Keys DN, Haga S, Hayashi H, Hino K, Imai KS, Inaba K, Kano S, Kobayashi K, Kobayashi M, Lee Bl, Makabe KW, Manohar C, Matassi G, Medina M, Mochizuki Y, Mount S, Morishita T, Miura S, Nakayama A, Nishizaka S, Nomoto H, Ohta F, Oishi K, Sano M, Sasaki A, Sasakura Y, Shoguchi E, Shin-i T, Spagnuolo A, Stainier D, Suzuki MM, Tassy O, Takatori N, Tokuoka M, Yagi K, Yoshizaki F, Wada S, Zhang C, Hyatt PD, Larimer F, Detter C, Doggett N, Glavina T, Hawkins T, Richardson P, Lucas S, Kohara Y, Levine M, Satoh N, Rokhsar DS: The draft genome of Ciona intestinalis: insights into chordate and vertebrate origins. Science 2002, 298:2157-2167.
6. Collén J, Roeder V, Rousvoal S, Collin O, Kloareg B, Boyen C: An expresseg sequence tag analysis of thallus and regenerating protoplasts of Chondrus crispus (Gigartinales, Rhodophyceae). J Phycol 2006, 42:104-112.

7. Roeder V, Collén J, Rousvoal S, Corre E, Leblanc L, Boyen C: Identification of stress gene transcripts in Laminaria digitata (Phaeophyceae) protoplast cultures by expressed sequence tag analysis. J Phycol 2005, 41:1227-1235.

8. Thornton JM, Todd AE, Milburn D, Borkakoti N, Orengo CA: From structure to function: Approaches and limitations. Nat Struct Biol Structural Genomics Supplement 2000:991-994.

9. Watson JD, Laskowski RA, Thornton JM: Predicting protein function from sequence and structural data. Curr Opin Struct Biol 2005, 15:275-284.

10. Sugar FJ, Jenney FE Jr, Poole FL, Brereton PS, Izumi M, Shah C, Adams MW: Comparison of small- and large-scale expression of selected Pyrococcus furiosus genes as an aid to high-throughput protein production. J Struct Funct Genomics 2005, 6:149-158.

11. Busso D, Poussin-Courmontagne P, Rose D, Ripp R, Litt A, Thierry JC, Moras D: Structural genomics of eukaryotic targets at a laboratory scale. Struct Funct Genomics 2005, 6:81-88.

12. Baneyx F: Recombinant protein expression in Escherichia coli. Curr Opin Biotechnol 1999, 10:411-421.

13. Fox BG, Goulding C, Malkowski MG, Stewart L, Deacon A: Structural genomics: from genes to structures with valuable materials and many questions in between. Nat Methods 2008, 5(2):129-132.

14. Structural Genomics Consortium, China Structural Genomics Consortium, Northeast Structural Genomics Consortium, Gräslund S, Nordlund P, Weigelt J, Hallberg BM, Bray J, Gileadi O, Knapp S, Oppermann U, Arrowsmith C, Hui R, Ming J, dhe-Paganon S, Park HW, Savchenko A, Yee A, Edwards A, Vincentelli R, Cambillau C, Kim R, Kim SH, Rao Z, Shi Y, Terwilliger TC, Kim CY, Hung LW, Waldo GS, Peleg Y, Albeck S, Unger T, Dym O, Prilusky J, Sussman JL, Stevens RC, Lesley SA, Wilson IA, Joachimiak A, Collart F, Dementieva I, Donnelly MI, Eschenfeldt WH, Kim Y, Stols L, Wu R, Zhou M, Burley SK, Emtage JS, Sauder JM, Thompson D, Bain K, Luz J, Gheyi T, Zhang F, Atwell S, Almo SC, Bonanno JB, Fiser A, Swaminathan S, Studier FW, Chance MR, Sali A, Acton TB, Xiao R, Zhao L, Ma LC, Hunt JF, Tong L, Cunningham K, Inouye M, Anderson S, Janjua H, Shastry R, Ho CK, Wang D, Wang H, Jiang M, Montelione GT, Stuart DI, Owens RJ, Daenke S, Schütz A, Heinemann U, Yokoyama S, Büssow K, Gunsalus KC: Protein production and purification. Nat Methods 2008, 5:135-146. Review

15. Bendtsen JD, Nielsen $H$, von Heijne G, Brunak S: Improved prediction of signal peptides: SignalP 3.0. J Mol Biol 2004, 340:783-795.

16. Krogh A, Larsson B, von Heijne G, Sonnhammer ELL: Predicting transmembrane protein topology with a hidden Markov model: application to complete genomes. J Mol Biol 2001, 305:567-580.

17. Quevillon E, Silventoinen V, Pillai S, Harte N, Mulder N, Apweiler R, Lopez R: InterProScan: protein domains identifier. Nucleic Acids Res 2005, 33:116-120

18. Lemesle-Varloot L, Henrissat B, Gaboriaud C, Bissery V, Morgat A, Mornon JP: Hydrophobic cluster analysis: procedures to derive structural and functional information from 2-D-representation of protein sequences. Biochimie 1990, 72:555-574.

19. Studier FW: Protein production by auto-induction in high density shaking cultures. Protein Expr Purif 2005, 41:207-234

20. Berrow NS, Büssow K, Coutard B, Diprose J, Ekberg M, Folkers GE, Levy N, Lieu V, Owens RJ, Peleg Y, Pinaglia C, Quevillon-Cheruel S, Salim L, Scheich C, Vincentelli R, Busso D: Recombinant protein expression and solubility screening in Escherichia coli: a comparative study. Acta Crystallogr D Biol Crystallogr 2006, 62:1218-1226.

21. Schein CD: Production of soluble recombinant proteins in bacteria. Biotechnol 1989, 7:1141-1148.

22. Nguyen H, Martinez B, Oganesyan N, Kim R: An automated small-scale protein expression and purification screening provides beneficial information for protein production. J Struct Funct Genomics 2004, 5:23-27.

23. Ren B, Kuhn J, Meslet-Cladiere L, Briffotaux J, Norais C, Lavigne R, Flament $D$, Ladenstein R, Myllykallio H: Structure and function of a novel endonuclease acting on branched DNA substrates. Embo J 2009, 28(16):2479-2489 
24. Collins BK, Tomanicek SJ, Lyamicheva N, Kaiser MW, Mueser TC: A preliminary solubility screen used to improve crystallization trials: crystallization and preliminary X-ray structure determination of Aeropyrum pernix flap endonuclease-1. Acta Cryst D-Biol Cryst 2004, 60:1674-1678.

25. Qin H, Hu J, Hua Y, Challa SV, Cross TA, Gao FP: Construction of a series of vectors for high throughput cloning and expression screening of membrane proteins from Mycobacterium tuberculosis. BMC Biotechnol 2008, 16:8-51

26. Wang BC, Adams MW, Dailey H, DeLucas L, Luo M, Rose J, Bunzel R, Dailey T, Habel J, Horanyi P, Jenney FE Jr, Kataeva I, Lee HS, Li S, Li T, Lin D, Liu ZJ، Luan CH, Mayer M, Nagy L, Newton MG, Ng J, Poole FL, Shah A, Shah C, Sugar FJ, Xu H: Protein production and crystallization at SECSG -- an overview. J Struct Funct Genomics 2005, 6(23):233-243.

27. Siaut M, Heijde M, Mangogna M, Montsant A, Coesel S, Allen A, Manfredonia A, Falciatore A, Bowler C: Molecular toolbox for studying diatom biology in Phaeodactylum tricornutum. Gene 2007, 406(12):23-35.

28. Geslin C, Gaillard M, Flament D, Rouault K, Le Romancer M, Prieur D, Erauso G: Analysis of the first genome of a hyperthermophilic marine virus-like particle, PAV1, isolated from Pyrococcus abyssi. J Bacteriol 2007, 189:4510-4519.

29. Stevens RC: Design of high-throughput methods of protein production for structural biology. Structure 2000, 8:R177-185.

30. Terpe K: Overview of tag protein fusions: from molecular and biochemical fundamentals to commercial systems. App/Microbiol Biotechnol 2003, 60:523-533.

31. Smith DB: Generating fusions to glutathione S-transferase for protein studies. Methods Enzymol 2000, 326:54-70.

32. Hochuli E: Purification of recombinant proteins with metal chelate adsorbent. Genet Eng (N Y) 1990, 12:87-98.

33. Lesley SA: High-throughput proteomics: protein expression and purification in the postgenomic world. Prot Expr Purif 2001, 22:159-164.

34. Cowieson NP, Listwan P, Kurz M, Aagaard A, Ravasi T, Wells C, Huber T, Hume DA, Kobe B, Martin JL: Pilot studies on the parallel production of soluble mouse proteins in a bacterial expression system. J Struct Funct Genomics 2005, 6:13-20.

35. Knaust RK, Nordlund P: Screening for soluble expression of recombinant proteins in a 96-well format. Anal Biochem 2001, 297:79-85.

36. Busso D, Kim R, Kim SH: Expression of soluble recombinant proteins in a cell-free system using a 96-well format. J Biochem Biophys Methods 2003, 55:233-240.

37. Vincentelli R, Canaan S, Offant J, Cambillau C, Bignon C: Automated expression and solubility screening of His-tagged proteins in 96-well format. Anal Biochem 2005, 346:77-84.

38. Braun $P$, LaBaer J: High throughput protein production for functional proteomics. Trends Biotechnol 2003, 21:383-388.

39. Büssow K, Scheich C, Sievert V, Harttig U, Schultz J, Simon B, Bork P, Lehrach $\mathrm{H}$, Heinemann $\mathrm{U}$ : Structural genomics of human proteinstarget selection and generation of a public catalogue of expression clones. Microb Cell Fact 2005, 5:21.

40. Gräslund S, Sagemark J, Berglund H, Dahlgren LG, Flores A, Hammarström $M$, Johansson I, Kotenyova T, Nilsson M, Nordlund $P$, Weigelt J: The use of systematic $\mathrm{N}$ - and $\mathrm{C}$-terminal deletions to promote production and structural studies of recombinant proteins. Protein Expr Purif 2008, 58:210-221.

41. Sambrook J, Fritsch EF, Maniatis T: Molecular cloning: A Laboratory Manual. Cold Spring Harbor, Cold Spring Harbor Press; 1989.

\section{doi: $10.1186 / 1475-2859-9-45$}

Cite this article as: Groisillier et al., MARINE-EXPRESS: taking advantage of high throughput cloning and expression strategies for the post-genomic analysis of marine organisms Microbial Cell Factories 2010, 9:45

\section{Submit your next manuscript to BioMed Central} and take full advantage of:

- Convenient online submission

- Thorough peer review

- No space constraints or color figure charges

- Immediate publication on acceptance

- Inclusion in PubMed, CAS, Scopus and Google Scholar

- Research which is freely available for redistribution

Submit your manuscript at www.biomedcentral.com/submit
C Biomed Central 